\title{
A constitution against parties: Madisonian pluralism and the Anti-party tradition*
}

That political parties did NOT hOLd a RESPECTABle PLACE IN I 8th-century American political theory was a reflection of the low place they were believed to hold in practice. Wherever the Americans looked, whether to the politics of Georgian England, their own provincial capitals or the republics of the historical past, they thought they saw in parties only a distracting and divisive force representing the claims of unbridled, selfish, special interests. I do not intend here to try to penetrate the thickets of 18 th-century politics either in England or in the American provinces. We long ago learned not to identify the Whigs and Tories of the 18 th century with the highly developed British political parties of modern times, and not to imagine that England had a well-developed two-party system at the close of the 18 th century or even during the first two decades of the I9th. Modern parties have grown up in response to (and in turn have helped to stimulate) the development of large electorates, and their institutional structures are in good measure an outgrowth of the efforts necessary to connect the parliamentary party and the mass party. The modern party is, in this respect, the disciplined product of regular party competition in the forum of public opinion. It also deals with legislative issues, over which the established parties differ. But this concern with issues and legislation - and hence with competing programmes - which we now take for granted in party politics did not have anything like the same kind of development in the politics of 18 th-century England or of the American colonies. ${ }^{1}$ It

* This essay is excerpted and abridged from the author's forthcoming volume, Jeffersonian Democracy and Political Parties, originally presented in 1966 as the Jefferson Memorial Lectures at the University of California, Berkeley, and to be published in 1969 by the University of California Press.

${ }^{1}$ Cf. Richard Pares: 'In the eighteenth century Cabinets existed to govern rather than to legislate, and parties to sustain government rather than legislation; ... when a minister legislated, even on important matters, he often did so as an individual, not only technically but politically. It did not often happen that a 
is the need to legislate regularly that imposes a constant discipline within a parliamentary body, as it is the need to carry issues to an electorate of considerable size that requires permanent organizations within the constituencies.

English politics in the mid-18th century, with the cabinet system not yet developed, with its relatively small electorate, its pocket boroughs, its connections of leading families, its management by purchase and arrangement, its lack of highly focused issues, its multiple, shifting factions, its high proportion of unaligned members of Parliament, bore only a vague germinal relation to the highly developed modern British party system. Historians may argue about details, but even as late as the I820s, Richard Pares once suggested, one should perhaps speak only of a tendency toward a two-party system. It was not until the election of 1830 that an opposition was formally recognized in a way which foreshadowed the modern procedure for a change of ministry. Wellington, finding that the election had left him without a working parliamentary majority, resigned on behalf of all his colleagues, recommending the chief leader of the opposition, Earl Grey, as his successor. ${ }^{2}$

Though today we think of the party system, party organization and party identifications among the electorate as being much more fully developed in Britain than in the United States, it is easy to see why 18th-century Americans found in the state of English politics little that was edifying and less to imitate. However we may now assess the English political system in the last half of the 18 th century, it seems safe to say that most Americans saw in it even less merit than it had, that they regarded it with a certain self-righteous puritanism, emphasizing its evil and corrupt character, which they contrasted with the robust and virtuous character of their own politics. Although there were still Anglophiles of a sort, one finds few Americans near the close of the century who could, with Hamilton, look upon English political culture, with all its faults, as the most advanced in the West, or who could understand why he thought it the only government in the world that united 'public strength with individual

party's programme consisted of legislation, or that the merits of a legislative proposal were, in any sense, put before the electorate.' King George III and the Politicians, 1953, p. I95. Cf. J. H. Plumb, Sir Robert Walpole: The Making of a Statesman, 1956, pp. 250-1.

2 Pares, King George III, p. 191; $f f$. pp. 182-207. The fluctuations and gradual growth of opposition and party politics are traced in Archibald S. Foord, His Majesty's Opposition, I7I4-1830, I964. 
security'. ${ }^{3}$ One can find perhaps none at all who could see in the historic division between Whigs and Tories any precursor of the highly functional party system of the future.

On the eve of the Revolution, most colonials thought of recent English history simply as a story of moral degeneracy, political corruption and increasing despotism, marking a sharp and perhaps irreversible decline from the glories of that earlier England whose principles had been the inspiration of American liberties. Indeed one reason for the Revolution was the felt necessity of severing connections with a state that was losing the pristine purity of its constitution and was cutting itself adrift upon the seas of corrupt and tyrannical government. Americans saw this corruption when they visited the mother country; they read about it in English political pamphleteers; they saw it at work on their own premises in the behaviour of the Customs Commissioners during the 1760 s.

Although the Americans thought of their own political condition as being much healthier than England's - it was in the New World that they expected old English liberties to be preserved - they thought they had no reason to attribute the comparative soundness of their own politics, as they saw it, to any evidences of party government. Though most historians would probably want to make an exception for Pennsylvania, and some perhaps for New York, most would agree with the general judgement that 'no colony had what could be appropriately designated as a party structure'. ${ }^{4}$ Certainly if a rigorous definition of party structure is laid down, demanding not merely parliamentary factions in the assemblies but clearly developed and permanent mass parties, this judgement would hold.

A great deal of political energy went into the repeated battles with the royal governors, and this put a premium on methods of organization that united rather than divided the assemblies. In the conduct of their struggles, and in securing legislation, the colonists had recourse to more or less disciplined caucusing groups, sometimes called 'Juntos' which made life difficult for the governors but greatly increased the effectiveness of those who wanted to assert colonial prerogatives. After $177^{6}$, with royal governors out of the way, the state legislatures, released from the unifying discipline imposed by the struggle for their prerogatives, were more free to break up into factional groupings. Political contests could now take on more

${ }^{3}$ Hamilton citing Necker to the Federal Convention, Max Farrand, ed., Records of the Federal Convention of 1787 , I 911, I, p. 288.

${ }^{4}$ Clarence Ver Steeg, The Formative Years, $1607-1763,1964$, p. 273. 
clearly the form of struggles between rival groups of citizens within the state. But of course many respectable men saw this period as one of alarming disorder, and they could see little promise of good in the local factionalism that developed. "To many, the very word "party" carried anti-republican connotations.' 5

Pennsylvania, which had the closest thing to a two-party system, was sometimes pointed to as an example of the evil effects of party strife under constitutional government. Madison, for example, in the fiftieth Federalist, cited the 'two fixed and violent parties' of Pennsylvania as a primary reason for the failure of that state's Council of Revision. The state had been 'for a long time before, violently heated and distracted by the rage of party', Madison pointed out, and this was a difficulty that the other states must also expect to experience. ${ }^{6}$ Yet one may wonder about the justice of this judgement on Pennsylvania. The factions in Pennsylvania may have been as bad as they were thought to be; the politics of that province had always been contentious; but the existence of parties did not prevent the Pennsylvanians from going through the fires of the Revolution, the British ensconced on their very doorstep, without slipping into tyranny or giving way to indiscriminate reprisals, or from emerging with a free and quite democratic constitution.

No doubt the factors that combined to produce free government were numerous, and party conflict was only one of them. Provincial factionalism had its seamy side and its social costs; and the pre-party factions may be criticized by contrast with the highly developed parties of a later day. But factional differences taught the Americans to argue, polemicize, legislate and on occasion to make compromises; the modern political party is an evolutionary product resting on a large fund of political experience, of which this early factional politics was a part.

The truth seems to be, however, that free government could struggle along with or without these rudimentary forms of party. Virginia must here concern us especially; and Virginia - which, along

${ }^{5}$ Richard P. McCormick, Experiment in Independence, p. 79; see Chapter IV of this work for an excellent account of political machinery in the 1780 . Carl L. Becker, in his History of Political Parties in the Province of Nen York, $1760-1776$ (r909), considered that parties, not very clearly defined, came into being in the i $760 \mathrm{~s}$, but concedes that before that date New York was still in the thrall of 'aristocratic methods of political management'. See pp. II-I8.

6 The Federalist, ed. by B. F. Wright, $196 \mathrm{x}$, pp. 353-4. On the party struggle before 1776 , see Theodore Thayer, Pennsylvania Politics and the Growtb of Democracy, 1740-1776, 1953. 
with Connecticut, was the least faction-ridden of the colonies - represents the strongest challenge to the notion that the political party had to be a force of decisive importance in the development of a free state. If we contemplate the political culture of the Old Dominion, which was, after all, the political culture that the Virginia dynasts knew best, the thing that strikes us most is its comparatively partyless condition and the extraordinary uneventfulness of its domestic politics in the I8th century up to $x_{7} 63$. One may argue whether the government of colonial Virginia was brilliant, but it was certainly competent as governments went then and as most of them go now; and Virginia bequeathed to the new nation a memorable if preponderantly parochial, gallery of talents, unmatched by any of the other states.

It is Virginia that may serve to remind us that, for all the claims that have been made for the 'democratic' character of colonial politics, colonial society was a deferential society and its politics were ordered accordingly. In his elegant little study of the methods of political control in Washington's Virginia, there was one conception for which Charles S. Sydnor had no use, beyond a need to explain its absence, and that is the conception of party. In 18thcentury Virginia men were elected not because of what they proposed to do about this or that issue but because of what they were. An election promise might be made here or there - though political promises were rather frowned on and might even be made the object of investigation or cause an elected candidate to be refused his seat but in the main men put themselves forward on their social position and character and manners, and on their willingness to treat their constituencies in the right and liberal fashion, not least on their willingness to ply them with rum punch. It was rare to run on issues or policies; and no one could run on factional identifications, since these were thin, ephemeral and spare of meaning. ${ }^{7}$

'Perhaps the most striking characteristic of Virginia politics between 1689 and 1763 ,' writes Jack P. Greene in his study of the Southern colonial assemblies, 'was its tranquillity.' Even the governors, he concludes, were in the main able, prudent and

${ }^{7}$ See C. S. Sydnor, Gentlemen Freebolders, 1952, esp. pp. 106-8, I I 5, 1 20-1. On the nature and significance of deferential society, see the brilliant essay by J. R. Pole, 'Historians and the Problem of Eatly American Democracy', American Historical Review, 67, 1962, pp. 626-46. On the transition from the politics of deference to those of public opinion and party debate in England and America, see Lloyd Irving Rudolph, 'The Meaning of Party', unpublished doctoral dissertation, Harvard University, 1956. 
moderate. The aristocracy was tightly knit and mutually accommodating. There was no serious rivalry between the Council and the Burgesses. Sectional divisions there were, but before the Revolution they were not of grave consequence. Class differences there were also, and occasional personal rivalries, but they produced no parties, not even permanent factions, and St George Tucker was able to recall with satisfaction long after the Revolution that he had never seen anything in the Burgesses 'that bore the appearance of party spirit'. 8

A generation nurtured in this environment had no successful example of party government anywhere in its experience, but it had an example of a partyless government of a free and relatively benign character, and all the statements of the Virginia dynasts about party, though conventional among their entire generation in America as well as in their own particular cherished locale, have a uniquely firm root in Virginia soil.

\section{THE BASIC SUSPICION}

Let us turn from the state of practice to the state of theory. The Founding Fathers, thinking along lines drawn by the old struggle against British authority, by the works of dissenters, radical Whigs and libertarian publicists, and by the violent pre-Revolutionary controversy itself, were concerned with one central issue: liberty versus power. Because men are fallible, wicked, and self-aggrandizing, they thought, power tends always to extend itself and to encroach upon liberty. 'From the nature of man', said George Mason at the Federal Convention, 'we can be sure that those who have power in their hands ... will always, when they can, ... increase it.' 'Power', said Madison, is of an encroaching nature.' 9 The basic problem of republicanism, as most of them saw it, was to protect liberty by devising foolproof checks upon power. The basic problem of good

${ }^{8}$ Jack P. Greene, The Quest for Power, 1963 , pp. 29-30; see also David Alan Williams, 'Political Alignments in Colonial Virginia, 1698-1750', unpublished doctoral dissertation Northwestern University, 1959, and Thad W. Tate, 'The Coming of the Revolution in Virginia: Britain's Challenge to Virginia's Ruling Class', Wrilliam and Mary Quarterly, 19, 1962, pp. 339-40, 343.

- Farrand, Records, I, P. 578; The Federalist (No. 48), p. 343. On the theme of power and liberty, see Bernatd Bailyn, The Ideological Origins of the American Revolution, 1967 , and on the late acceptance of parties in formal political theory, Austin Ranney, 'The Reception of Political Parties into American Political Science', South-Western Social Science Quarterly, 32, I951, pp. 183-91. 
American republicans like Madison, who nevertheless wanted a stronger Union, was to protect liberty by checking power, without at the same time weakening government to a point at which its stability would be in danger.

Liberty, then, was the basic value. As to what it consisted of, Americans sometimes assumed so much that their passionate claims for liberty seemed to mask a demand for licence or anarchy. But they would have answered that liberty prevailed when men were free to exercise their natural rights. As an answer to the abstract question, What is liberty? this was enough for them, and they had no difficulty at all in spelling out what natural rights were or what institutions threatened liberty or sustained it. It was endangered by many things they saw in contemporary England: monarchy and aristocracy, a standing army, corruption, bribery and patronage, a decadent state of morals. It could best be protected under a government which had within it a strong popular house in the legislature, a broad freehold suffrage, a system of mutual checks and balances among the arms of government, an independent judiciary, explicit guarantees of tights (among these, civil and religious liberties and trial by jury) and frequent (some said annual) elections.

The necessity of checks on power is a theme struck over and over. But it is important that for the Fathers these checks had to be built into the constitutional structure itself. They were not content - and still less were the people they had to persuade - to rest their hopes on those checks that might arise in the political process alone, and this is one reason why they put no faith in party competition. Their hopes were pinned on a formal, written system of internal checks and balances, the precise enumeration of limited powers and the explicit statement of constitutional guarantees, such as the opponents of the Constitution insisted on adding to it. Such informal forces in politics as the temper of the public, the process of opposition, the institutionalization of party structures, which to us seem so vital in democracy, seemed to them too slender to rely on and an inadequate substitute for explicit constitutional specifications.

Here, it is important to realize, the ideas about constitutional structure that prevailed in America were derived both from AngloAmerican experience and from the traditions of classical political thought. What had come down as the authoritative prescription for just and stable government from the times of Polybius and Aristotle was the idea of mixed government - that is, a government that would incorporate representation of the three basic orders in society. The 
three indispensable arms of government would act for the sovereign, the nobility and the people. The prevalent 18 th-century passion for balanced government, which was founded on the conviction that liberty and justice would be most secure if the elements of the state and of society were counterposed in such a way as to check and control each other, was sought for in constitutional systems that separated the powers of government and put the several arms of government in a state of watchful mutual tension. The necessary mutual checks would thus be provided by the elements of the constitution, and not by parties, which were indeed usually thought of, when they were thought of at all, as forces likely to upset the desired constitutional balance by mobilizing too much force and passion in behalf of one limited interest.

When they were thought of at all: in classical political theory, in the great books from Aristotle to Machiavelli and Montesquieu which were read by the Founding Fathers when they consulted literature for political wisdom, parties played only an incidental, illustrative historical role, usually as examples of some difficult problem or some historical mischief. Most of the classical political writers had mentioned party here and there, but none of them discussed parties at substantial length or offered a theory of the role of the party in the state. Even such empirically minded thinkers as Aristotle and Machiavelli had little to say on the subject; and so strong was this tradition that even as late as $\mathrm{x} 86 \mathrm{I}$, long after his own country was firmly launched upon the development of its two-party system, John Stuart Mill could write an entire treatise, Considerations on Representative Government, in which he never elaborated upon the role of party. Indeed, it was the great cumulative and collective merit of writers like Bolingbroke, Hume, Burke and Madison that they showed a new understanding of the importance of party and a strong disposition to move it somewhat closer to the centre of concern in political thought.

However, the point remains that in the thinking of the Founding Fathers, the truly useful and reliable antitheses of politics, the counterpoises upon which they were disposed to rely for liberty and stability, were still embodied not in the mutual checks of political parties but in the classic doctrine of the separation of powers, in the mutual checks of the houses of legislature or in the checks exerted upon each other by the executive and the legislature, and in that exerted by the judiciary over the other two. Checks were to be built into planned constitutional forms instead of being left to the 
hurly-burly of politics. James Madison, for example, assuring the Federal Convention that the new constitution would have safeguards against the betrayal of trust by officials, explained: 'An obvious precaution against this danger would be to divide the trust between different bodies of men, who might watch and check each other.' John Jay, speaking for the Constitution in the New York ratifying convention, said: 'The two houses will naturally be in a state of rivalship. This will make them always vigilant, quick to discern a bad measure, and ready to oppose it.' ${ }^{10}$ It was two bouses, not two parties.

While most of the Fathers did assume that partisan oppositions would form from time to time, they did not expect that valuable permanent structures would arise from them which would have a part to play in the protection and exercise of liberties or in reconciling the stability and effectiveness of government with the exercise of popular freedoms. The solution, then, lay in a nicely balanced constitutional system, a well-designed state which would hold in check a variety of evils, among which the divisive effects of parties ranked high. The Fathers hoped to create not a system of party government under a constitution but rather a constitutional government that would check and control parties.

This conviction, as Cecelia Kenyon has pointed out, was shared by both sides in the debate over the adoption of the Constitution. Although Federalists and Anti-Federalists differed over many things, they did not differ over the proposition that an effective constitution is one that successfully counteracts the work of parties. The AntiFederalists often expressed a sweeping opposition to the idea of political organization as such, and, as Miss Kenyon has observed, "the contemporary opponents of the Constitution feared parties or factions in the Madisonian sense just as much as did Madison, and ... they feared parties in the modern sense even more than Madison did. They feared and distrusted concerted group action for the purpose of "centering votes" in order to obtain a plurality, because they

${ }^{10}$ Farrand, Records, I, $42 \mathrm{I}$; Jonathan Elliot, Debates in the Several State Conventions, II, r888, p. 285. Cf. Madison in Number 5I, where he argues that one should so contrive 'the interior structure of the government as that its several constituent parts may, by their mutual relations, be the means of keeping each other in their proper places'. Again, the way to avoid excessive legislative predominance is 'to divide the legislature into different branches; and to render them, by different modes of election and different principles of action, as little connected with each other as the nature of their common functions and their common dependence on the society will admit'. Federalist, pp. 355, 357 . 
believed this would distort the automatic or natural expression of the people's will.'11

\section{PARTIES AS SECTS}

We have come now to the point at which we can examine the problem of party as it was expressed in the minds of the Virginia dynasts. Its seems fitting to begin with Madison: he was a more systematic, and I believe a more deliberate and profound thinker than Thomas Jefferson; as the philosopher of the Constitution, he gives the clearest and most authoritative statement of the conflict between the rationale of the Constitution and the spirit of the party; and, as the man who began, before Jefferson, to play the central role in organizing what came to be considered Jefferson's party, he illustrates even more sharply than Jefferson our central paradox of party government instituted by anti-party thinkers.

The great achievement of Madison was to provide for his contemporaries a statement of the checks-and-balances view of government in which a pluralistic view of society itself was linked to the plural constitutional structure. Like John Adams, he saw with great clarity the importance of supplementing the internal balance of the constitution with the external balance of the various interests and forces that make up society.

Here Madisonian pluralism owes a great deal to the example of religious toleration and religious liberty that had already been established in 18 th-century America. The traditions of dissenting Protestantism had made an essential contribution to political pluralism. That fear of arbitrary power which is so marked in American political expression had been shaped to a large degree by the experience men of dissenting sects had had with persecution. Freedom of religion became for them a central example of freedoms in general, and it was hardly accidental that the libertarian writers who meant so much to the colonials so often stemmed from the tradition of religious dissent. In the colonies, Americans fought unrelentingly against the proposal to introduce an Anglican episcopate among them, an idea that excited in their minds a remarkable terror that religious liberty, and then all liberty, would be invaded. In their

${ }^{11}$ See her 'Introduction' to her documentary anthology, The Antifederalists, 1966, cx; cf. 1v, 1xxxv, xciii-xciv; see also her essay, 'Men of Little Faith: the Antifederalists on the Nature of Representative Government', William and Mary Quarterly, Third Series, XII, 1955, p. 40; $f f$. pp. $13,36$. 
campaign against an American episcopate, the colonials co-operated with dissenters in the mother country with such admirable system and regularity that they established a veritable trans-Atlantic Protestant anti-episcopal union, whose members gave a great deal of thought to the problems of liberty, toleration and pluralism. ${ }^{12}$

In 1768 an Anglican chaplain was quoted by one of his antiestablishment opponents in New York as having said that American experience showed that 'republican principles in religion naturally engender the same in civil government'. It was an appropriate remark. The whole Protestant enterprise had made for the decentralization of structure within the churches themselves and at the same time within the structure of society. There was no longer a State and a Church standing together in a single, firm, ordered hierarchy, but two spheres of values that could sometimes compete. The presence of dissenters, and the necessity of appeasing them in the interests of secular stability, meant that the imperatives of the state and those of the church might not coincide, and that the latter might in some respects be sacrificed for the former. The presence of a variety of theologies, a plurality of views within Protestantism itself, also made toleration a necessary precondition for the secular values of peace and social stability. The co-existence of the sects and the growth of toleration led to a premium on argument and persuasion, as against main force. The dissenters, with the law against them and no other instrument of suasion available to them, had had to defend their interests in this way. It became clear in England that there could no longer be such a thing as a single enforceable orthodoxy. Even error had to be tolerated, and if error could be endured where profound matters of faith were concerned, a model had been created for the political game, in which also one had to learn to endure error in the interests of social peace. ${ }^{13}$

Of course, the advancing secularism of educated men brought great reinforcement to this tendency. One notices the common sense of relief shared by such different theorists of party as Bolingbroke, Hume and Burke at the passing of the old religiously-inspired bigotry-animated political divisions of the 17 th century, and Hume indeed had made a central principle of it in his political writings. The advanced, enlightened, more or less secular man could take a genial view of the competitions of sects, so long as they were all free and

12 For a full account of this movement, see Carl Bridenbaugh, Mitre and Sceptre, 1962.

13 Ibid., pp. 306n, 52 , 
not at each others' throats. So Franklin, a Deist, patronized the churches, and Jefferson in time forged a curious political alliance between Enlightenment liberalism and the passion of the minority sects for religious freedom. ${ }^{14}$

The intellectual transition from the pluralism engendered by religious denominations to that of parties was clearly illustrated by William Livingston in New York during the 1750s. A young man still in his late twenties when he started writing in 1752 , Livingston was soon to cut quite a figure in the politics of the province as a partisan in the De Lancey-Livingston party battle. The De Lanceys were Anglicans, the Livingstons and their allies Presbyterians and keen enemies of episcopacy. In 1752 Livingston launched his Independent Reflector, a journal which was to ape the style of the Tatler and the Spectator but which took much of its argument from Cato's Letters. Though a strong partisan, Livingston had been put off by strong, dogmatic doctrinal religion at Yale, and his Presbyterianism was qualified by a certain broad tolerance of other dissenting groups and yet fortified by an intense, almost anticlerical animus against the Anglican Church. His own doctrines on faction were hewn out of the current orthodoxy. ("Unspeakably calamitous have been the consequences of party-division. It has occasioned deluges of blood, and subverted kingdoms.') But still, as an ardent partisan, Livingston, like Bolingbroke with his country party to end all parties, had to have an exception: 'To infer . . . that the liberties of the people are safe and unendanger' $d$, because there are no political contests, is illogical and fallacious.' We all have a right to look into the conduct of our superiors, and if we find in them 'a combination of roguery' it is our common right to 'form a party against their united strength: and such a party, I hope we may never want the spirit to form' ${ }^{15}$

Livingston, who never lacked such spirit, was roused to one of his keenest efforts in 1753 during the controversy over the founding of King's College (later Columbia). He was afraid that the college, should it receive a charter from the Crown, would become an exclusively Anglican institution, 'an academy founded in bigotry and reared by party-spirit'. He proposed instead that the college should

14 For this alliance see Sidney E. Mead, 'American Protestantism during the Revolutionary Epoch', Cburch History, 12, 1953, pp. 279-97.

${ }_{15}$ The Independent Reflector, ed. by Milton Klein, 1963, pp. 146, 148. On the significance of this controversy, see Klein's Introduction, and Richard Hofstadter and Walter P. Metzger, The Development of Academic Freedom in the United States, I955, pp. 187-9I. 
be created by the legislature, and established on such a non-sectarian basis that all the groups in the province could use it together, and that all the youths sent there could be educated free of indoctrination in any particular set of religious or partisan tenets. 'For as we are split into so great a variety of opinions and professions; had each individual bis share in the government of the academy, the jealousy of all parties combating each other, would inevitably produce a perfect freedom for each particular party.' Next to a patriot king and wise laws, Livingston argued, 'an equal toleration of conscience is justly deem'd the basis of the public liberty of this country. And will not this foundation be undermined? Will it not be threatened with a total subversion, should one party obtain the sole management of the education of our youth?' 16

Note that the term 'party' is applied by Livingston more or less indifferently to a religious or a political group, a circumstance that arises not only out of their interconnection in the provincial politics of New York but also, and more importantly, out of his understanding of the principles of mutuality involved both in religious liberty and civic peace. For him libertarian principles in religion did indeed have a bearing on the problems of civil government.

A similar awareness of the relation between multiple sects and liberty is evident in a remarkable sermon delivered by the Reverend Ezra Stiles in 1760 and published the following year. Stiles was really addressing the Congregational world of New England, which, though badly divided for twenty years by the effects of the Great Awakening, was still united in its anxiety about episcopal incursions. In his $A$ Discourse on the Christian Union Stiles pleaded for an ecumenical tolerance. 'Every sect', he said, 'have a right to vindicate their particular forms.' Theological differences, which he hoped to minimize among good Christians, might survive, but: 'Their conviction ... is not to be laboured by the coercion of civil or ecclesiastical punishment, but by the gentle force of persuasion and truth - not by appeals to the tenets of parties and great men; not by an appeal to the position of Arminius or Calvin; but by an appeal to the inspired writings.' In arguing that even church councils or consociations had no authority over individual churches, Stiles added strikingly: 'Coercive uniformity is neither necessary in politics nor religion.' 'This conclusion was premised upon a remarkable statement of harmony in plurality:

Providence has planted the british America with a variety of sects, which will unavoidably become a mutual balance upon one another. Their

${ }^{16}$ Independent Reflector, pp. 184, 195, 213: italics added. 
temporary collisions, like the action of acids and alcalies, after a short ebulition will subside in harmony and union, not by the destruction of either, but in the friendly cohabitation of all. . . . Resplendent and allpervading TRUTH will terminate the whole in universal harmony. All surreptitious efforts and attempts on the public liberty will unavoidably excite the public vigilance of the sects, till the terms of general union be defined and honorably adjusted. The notion of erecting the polity of either sect into universal dominion to the destruction of the rest, is but an airy vision ... all the present sects will subsist and increase into distinct respectable bodies, continuing their distinctions for a long time yet to come in full life and vigor. Indeed mutual oppression will more and more subside from their mutual balance of one another. Union may subsist on these distinctions, coalescence only on the sameness of public sentiment, which can again be effected in the Christian world only by the gentle but almighty power of truth. ... The sects cannot destroy one another, all attempts this way will be fruitless. ... Nothing however will content us but actual experiment - this experiment will be made in one century, and then perhaps we shall be satisfied. ${ }^{17}$

It remained for James Madison to make still more explicit than Livingston or Stiles the analogy between the religious and the civic spheres. From his earliest days Madison had had a deep and passionate commitment to religious liberty. At twenty-three, he denounced 'that diabolical Hell conceived principle of persecution' and the Anglican clergy for abetting it, and professed that this troubled him more than any other public issues. Later it was Madison who would take the leadership in the struggle to go beyond the limited principle of toleration, to espouse complete religious liberty and achieve disestablishment in the first constitution of Virginia. 18

As Madison was well aware in the less discouraged moments of his maturity, an answer to the 'hell-conceived principle' of religious persecution was already apparent in America. The growth of a multiplicity of denominations and sects had made religious freedom a practical necessity, and had provided the political forces to make it possible. Madison's insight into the strength and viability of a pluralistic society seems at least to have been heightened, if it did not derive from, the model, already before him, of various religious groups coexisting in comparative peace and harmony. He told the Virginia Ratifying Convention of 1788 that the remarkable freedom

17 A discourse on the Christian Union, I761, 53, 95, 96-97; cf. Bridenbaugh, Mitre and Sceptre, Chapter I.

18 Papers, ed. by W. T. Hutchinson and W. M. E. Rachal, I, I962, pp. 1o1-6, 107, I I I-r 3, 1 59, 170 ff.; Irving Brant, James Madison: The Virginia Revolutionist, I $94 \mathrm{I}$, pp. 65-77, 85, 1 28-30, $243 \mathrm{ff}$. 
of religion now achieved 'arises from that multiplicity of sects, which pervades America, and which is the best and only security for religious liberty in any society. . . . The United States abound in such a variety of sects, that it is a strong security against religious persecution, and it is sufficient to authorize a conclusion that no one sect will ever be able to outnumber or depress the rest.' ${ }^{19}$

A monopolistic religious establishment is in a position to persecute, just as a single interest in society or a single arm of government, when unchecked, is in a position to be tyrannical. A plurality of sects militates against religious oppression just as a plurality of varying social interests militates against political oppression. Madison put this analogy very explicitly in Number $\mathrm{s}$ of The Federalist, where he spoke of the desirability of guarding against the oppression of minorities by a single consolidated majority. This, he thought, could be done in the proposed federal republic of the United States 'by comprehending in the society so many separate descriptions of citizens as will render an unjust combination of a majority of the whole very improbable, if not impracticable'. While all authority in the proposed republic, he went on, 'will be derived from and dependent on the society, the society itself will be broken into so many parts, interests, and classes of citizens, that the rights of individuals, or of the minority, will be in little danger from interested combinations of the majority. In a free government the security for civil rights must be the same as that for religious rights. It consists in the one case in the multiplicity of interests, and in the other in the multiplicity of sects. The degree of security in both cases will depend on the number of interests and sects; and this may be presumed to depend on the extent of country and number of pcople comprehended under the same government." 20

\section{PLURAIISM AND PLURIPARTISM}

The best statement of Madison's pluralism, of course, is in the familiar Number Ten of The Federalist, a work which shows a powerful obligation to the theory of party laid down in David Hume's

19 Elliot, Debates, III, p. 330; see also Madison, Writings, Hunt, ed., II, p. $185 ; \mathrm{V}, \mathrm{p} .176$.

20 The Federalist, p. 358, italics added; $c f$. Farrand, Records, I, pp. 134-6 for his speech in the Convention of 1787 ; and Writings, V, pp. 123-9 for his speech in the Virginian Convention. 
essays. ${ }^{21}$ Madison's basic concern in that essay was to show that a large federal union would be better than a small republic at sustaining free representative government; but his point of departure was the problem of controlling parties and the 'violence' and threat to liberty that are connected with them. Always, in The Federalist, the fundamental thing government has to control is the assertive selfishness of human nature. But the basic manifestation of this selfishness in political life is the party, or faction. Possibly the greatest of the many advantages that would come with a well-constructed Union, Madison argued, was its tendency to break and control the violence of faction'. (Madison, it should be noted, used the terms party and faction as synonyms. ${ }^{22}$ ) The classical problem of the republics known to previous history, their instability, injustice and confusion, had already been much remedied by the constitutions of the American states, he admitted. But now complaints were being heard everywhere by public-spirited men that 'the public good is distegarded in the conflicts of rival parties' - and particularly that measures were being decided 'by the superior force of an interested and overbearing majority'. Such injustices were largely if not wholly the consequence of 'a factious spirit' in government. 'By a faction', Madison goes on, 'I understand a number of citizens, whether amounting to a majority or a minority of the whole, who are united and actuated by some common impulse of passion, or of interest, adverse to the rights of other citizens, or to the permanent and aggregate interests of the community.' ${ }^{23}$

How best to remedy this state of affairs? You can destroy liberty, which makes faction possible, but that remedy is clearly far worse than the disease. You can try to give all citizens the same opinions, passions and interests, but that is impracticable. Men have different

21 For the text, see The Federalist, pp. 129-36. The composition of this remarkable essay had gone on for some period of time. The basic analysis had been stated and restated in letters and in his 'Observations' of April 1787. See Writings, II, pp. 273, 346-7, 366-9; V, pp. 28-32. It is important also, on this theme, to read The Federalist, Numbers $14,37,47,48$, 50 and $g x$.

22 For example: '.. and the most numerous party, or, in other words, the most powerful faction must be expected to prevail'. The Federalist, No. IO, p. 132. See, on this, the useful textual comparisons made by Gottfried Dietze in The Federalist: $A$ Classic on Federalism and Free Government, 1960, p. I 9 n.; Dietze also points out (p. I06) that Hamilton and Jay used the terms in the same way; cf. B. F. Wright in his edition of Tbe Federalist, p. 33.

${ }^{23}$ Note that where Burke had defined party as based on principles aiming to advance the common interest, Madison defines it as based on passions or interests that threaten the general welfare. 
faculties and different abilities in acquiring property; and protecting these faculties is the first object of government. But out of these differences arise different kinds and degrees of property, hence differing political interests and parties. 'The latent causes of faction are thus sown in the nature of man.' Passions will make men form factions and 'vex and oppress each other'. But different propertied interests - landed, moneyed, mercantile, manufacturing, debtors and creditors - are the most common and durable sources of factions. 'The regulation of these various and interfering interests forms the principal task of modern legislation, and involves the spirit of party and faction in the necessary and ordinary operations of government.'

'This last sentence, because of the ambiguity of the word 'involves', has led some readers to think that Madison found a strong positive function for parties after all. But it is one thing to say that legislation or government cannot be carried on without having parties make their appearance - i.e., that they are involved - and another that they are valuable in the process; and I think the whole context of Madison's work, with its pejorative definition of party and its many invidious references to party, make it clear that it was the former meaning he was trying to convey.

Since the causes of faction cannot be safely or wisely removed, Madison was saying, we have to look for relief in the means of controlling its effects. The most dangerous faction is the most powerful, the majority faction, and it is above all the tyranny of the majority that we must be concerned with. A minority faction, he admitted, could be temporarily obstructive, and could even convulse society. But in the normal course of events in a republic, it will be outvoted, and it will be 'unable to execute and mask its violence under the forms of the Constitution'. However, a majority faction can sacrifice the public good and the rights of other citizens to its ruling passion, and it is this above all that must be prevented. 'To secure the public good and private rights against the danger of such (majority) faction, and at the same time to preserve the spirit and form of popular government, is then the great object to which our inquiries are directed.'

How can this be done? It is useless to rely on enlightened statesmen: they may not always be there; and it is the very essence of good constitution-making to provide safeguards against ordinary human frailties. ${ }^{24}$ The answer lies in a representative republic, which will

${ }^{24} C f$. Hume, Essays, 1, 99: 'But a republican and free government would be an obvious absurdity, if the particular checks and controls, provided by the 
avoid the turbulence of direct democracy, and in an extensive republic rather than a small one.

In making this last point, Madison was trying to establish a view which thus far had had the status of a heresy. It was standard I 8thcentury doctrine - made canonical by Montesquieu though questioned by Hume - that republican governments, whatever their merits, are not strong enough for the government of an extended territory. Madison was concerned to assert the opposite: that an extended territory such as that of the United States bodes well for the survival and stability of representative republican government precisely because, being large, it embraces a healthy and mutually balancing variety of economic and social interests. It is just this plurality and variety that he believes will prevent the emergence of a cohesive and oppressive majority. 'Extend the sphere, and you take in a greater variety of parties and interests; you will make it less probable that a majority of the whole will have a common motive to invade the rights of other citizens; or if such a common motive exists, it will be more difficult for all who feel it to discover their own strength, and to act in unison with each other.' 25

In a large federal republic, Madison argued, a majority faction was less likely to be achieved than in a small one. The greater variety of parties is the greatest security 'against the event of any one party being able to outnumber and oppress the rest'. Thus the parties themselves are mobilized against the great danger of party. A multilateral equipoise, a suspended harmony of conflicting elements, very Newtonian in conception, is established. In Pope's words:
Not chaos-like, together crushed and bruised
But, as the world harmoniously confused
Where order in variety we see,
And where, though all things differ, all agree.

With the Madisonian formulation, thinking on the role of party had thus reached a stage of profound but fertile ambiguity. To unravel the ambiguity would require an entire additional generation of political experience.

Certain aspects of the Madisonian model require comment here,

constitution, had really no influence, and made it not the interest, even of bad men, to act for the public good.'

${ }^{25}$ In The Federalist, Number Nine, Hamilton had tackled the same problem by trying to show that even Montesquieu had seen the confederation of republics as an answer to the problem of size. 
since they point to difficulties unresolved either in the theory or the construction of the Constitution. Madison is not, for example, totally clear just by what mechanism the formation of an oppressive majority is to be prevented. It is not certain whether he is saying that in a properly balanced society under a properly balanced constitution it will be impossible for a majority to form at all, or whether he simply believes that the majority, if formed, will be too weak or too impermanent, or both, to execute its 'schemes of oppression'. But more important than this is the question whether Madison has left room enough in his ingenious model for the formation of a majority sufficiently effective to govern at all. If the 'energetic' government he and Hamilton sought was to become a reality, it would surely carry out a number of policies of sweeping consequence for the people, policies which in most cases would be the object of doubt and dispute. How could any such policies be formed and executed, if not through the periodic formation of majority coalitions? Again, how could they be better legitimated under a republican system than by reference to the majority will? Madison himself would soon enough begin to see the cogency of these questions.

Another problem that has stimulated much comment is that Madison seems to show little fear of minority tyranny or even of minority obstruction, both of which he dismisses in a phrase. $\mathrm{He}$ does not address himself to the possibility that, since majorities are to be weak and precarious, a large, aggressive minority, though incapable of taking the reins of government, might veto whatever policy it likes and thus, in effect, tyrannize over the majority. ${ }^{26}$ There is, in short, no protection of the majority against grave deprivations imposed by the minority. And as we shall see in due course, Madison was forced to confront this possibility near the end of his life, when he was compelled in his opposition to nullification to rephrase his view of the majority. Neither, it must be added, does Madison address himself to the possibility that a minority interest in the population, by virtue of superior wealth, organization and influence, can actually come into the firm possession of power against a pluralistic and divided majority. Yet within a few years after the Constitution was in operation this was precisely what the leaders of the emergent Republican party were saying about the Federalists.

Then, again, Madison's argument hardly anticipates the next step in the political game. What was he to say about the dangers of a

${ }^{26}$ See Robert A. Dahl, A Preface to Democratic Theory, I956, pp. 27-9, and more generally, Chapter I, 'Madisonian Democracy'. 
majority coalition when his own party, the Republicans, had finally organized one? Were the Republicans a faction or party in the sense in which Madison had used that word? Were they too, then, a danger to liberty? Were they a danger to liberty when, having two of the arms of government and finding the opposition entrenched in the third, the judiciary, they tried to subordinate the third arm also? Was this a fatal invasion of the sacred principle of the separation of powers?

There is another set of problems arising from the tension between Madison's two great objectives, to create a more 'energetic' national government and to protect liberty. Professor Alpheus T. Mason has remarked that The Federalist was a 'split personality'. Certainly there was a breach between Hamilton's clear and uncluttered concern for greater governmental energy and his tendency to consider that in a country like America liberty would be sure to take care of itself, and Madison's passionate desire, without sacrificing energy, to check the majority, to be sure that liberty was secured in a more certain way than had ever been done in the history of republics. ${ }^{27}$

The balance of social interests, the separation and balance of powers, were meant to secure liberty, but it was still uncertain, after the instrument had been framed and ratified, whether the balance would not be too precarious to come to rest anywhere; and whether the arms of government, separated in the parchment, could come together in reality to co-operate in the formation and execution of policy. As we shall see, a mechanism had to be found, for example, by which men could put together what God, in the shape of the Constitution, had sundered - to make it possible for the President and Congress to work in harness. Both the Federalists and the Republicans had to find a solution to this - the Federalists by making Hamilton a kind of prime minister to bridge the gap, and the Republicans by having President Jefferson exert through his agents and his direct influence a great power in Congress. The framers, discussing the method of election of the President, had expressed a good deal of concern that this should not happen - that the Executive should not be in league with, or the leader of, a party. But both sides, in order to make policy, found the agency of party a practical necessity. And in the end it was doubtful how this Constitution, devised against party, could have been made to work if such a functional

${ }^{27}$ Alpheus T. Mason, 'The Federalist - A Split Personality', American Historical Review, 57, 1952, pp. 625-43, esp. pp. 636 ff. 
agency as the party had not sprung into the gap to remedy its chief remaining deficiencies.

At an early point, then, parties were to become a part of the machinery of government in a manner that went well beyond Madison's resigned acceptance of them as evils that would always be there. In a country which was always to be in need of the cohesive force of institutions, the national parties, for all their faults, were to become at an early hour a primary and necessary part of the machinery of government. So much so that we may say that it was the parties that rescued this Constitution-against-parties and made of it a working instrument of government. When Lord Bryce came to evaluate American government in The American Commonwealth, he noted:

The whole machinery, both of national and State governments, is worked by the political parties. ... The spirit and force of party has in America been as essential to the action of the machinery of government as steam is to a locomotive engine; or, to vary the simile, party association and organization are to the organs of government almost what the motor nerves are to the muscles, sinews, and bones of the human body. They transmit the motive power, they determine the direction by which the organs act. ... The actual working of party government is not only full of interest and instruction, but is so unlike what a student of the Federal Constitution could have expected or foreseen, that it is the thing of all others which anyone writing about America ought to try to portray. ${ }^{28}$

A final word must be said about the character of Madison's pluralism. His was a pluralism among the parties, whereas the course of our national history has produced a pluralism within the parties. It was natural for Madison in $1787-88$ to think of the country as having not merely a wide variety of interests but also a rather wide variety of party groupings and subgroupings within the states. Historians will almost certainly disagree about the details, but Forrest McDonald's delineation of the various political factions existing during the Confederation may be suggestive. He found, leaving out a miscellany of very small factions, one state (Pennsylvania) with two parties, five states with two major factions, five with three or four major factions and one (Delaware) with multiple cliques. ${ }^{29}$ We need not be surprised that Madison's thought had to be adapted to this

${ }^{28}$ The American Commonwealth, 3 rd ed., I897, I, p. 6; II, pp. 3, 4.

29 Forrest McDonald, We the People, I 958, Chapter II. On Delaware, however, see John A. Munroe, Federalist Delaware, 1954, pp. 97-ro9, who finds two basic factions here also. 
existing political disorganization - thirteen states, each in its way a kind of separate political interest, and all together containing within them something like thirty discernible political groupings. What Madison did not see in advance was that the Constitution, by focusing more attention on nationwide issues, and indeed by itself first becoming a nationwide issue, would become a major force, perhaps the major force, in creating two great parties, and thus, ironically, making more probable the very majority coalition he so much feared; and, still more ironically, putting Jefferson, and then himself, at the head of such a majority. What happened in due course, as it is so easy for us to see, was that our social pluralism made itself effective within each of the two major parties, a process that was observable in Jeffersonian ranks by I 804 , if not earlier. In our politics each major party has become a compound, a hodge-podge, of various and conflicting interests; and the imperatives of party struggle, the quest for victory and for offices, have forced the parties themselves to undertake the business of conciliation and compromise among such interests. This business goes on not merely in the legislative process, where Madison expected it would, but also in the internal processes of the great political parties themselves.

Madison's pluralism, then, had great merits as a generalized model, but as to the parties it was mislocated. Envisaging political parties as limited, homogeneous, fiercely aggressive, special interests, he failed to see that the parties themselves might become great, bland, enveloping coalitions, eschewing the assertion of firm principles and ideologies, embracing and muffling the struggles of special interests; or that they might forge the coalitions of majorities that are in fact necessary to effective government into forces sufficiently benign to avoid tyranny and sufficiently vulnerable to be displaced in time by the opposing coalition. Liberty, he had always understood, would sustain a political atmosphere in which a conflict of parties would take place. The reverse of that proposition, the insight that underlies our acceptance of the two-party system, that the conflict of parties can be made to reinforce rather than undermine liberty, was to be well understood only in the future. 